\title{
SIMULASI NUMERIK PERSAMAAN GELOMBANG AIR DANGKAL UNTUK KASUS BENDUNGAN BOBOL
}

\section{NUMERICAL SIMULATION OF SHALLOW WATER EQUATION FOR DAM-BREAK CASE}

\author{
Raditya Panji Umbara \\ Pusat Teknologi Reduksi Risiko Bencana (PTRRB) - BPPT \\ Gedung 820, GEOSTECH, PUSPIPTEK, Kota Tangerang Selatan, telepon: (021) 75791378 \\ e-mail: raditya.panji@bppt.go.id
}

\begin{abstract}
Technological failure and natural disasters that caused the dam-break resulted in huge losses, both material loss and loss of life. The mathematical model for the dam-break can use the shallow water equation. In this paper, modeling the dam-break in two dimensions is solved by using the finite volume method with a staggered-grid scheme. The staggered-grid scheme produces more accurate when compared to the Lax-Friedrichs scheme. The stability of the water waves on the part of the damaged dam wall are also well preserved using a staggeredgrid scheme. Modeling a dam-break with real bathymetric data will be a challenge for further research because it involves a more complex geometry.
\end{abstract}

Keywords: shallow water equation, dam-break, numerical simulation, finite volume method, staggered-grid, technological failure, natural disaster

\begin{abstract}
ABSTRAK
Kegagalan teknologi maupun bencana alam yang menyebabkan bendungan bobol mengakibatkan kerugian yang besar, baik itu kerugian materiil maupun kerugian hilangnya korban jiwa. Model matematika untuk pendekatan bendungaan bobol dapat menggunakan persamaan air dangkal. Pada tulisan ini, pemodelan bendungan bobol dalam dua dimensi diselesaikan menggunakan pendekatan metode volume hingga dengan skema staggeredgrid. Skema staggered-grid menghasilkan hasil yang lebih akurat apabila dibandingkan dengan skema Lax-Friedrichs. Kestabilan gelombang air pada bagian dinding bendungan yang jebol juga terjaga dengan baik menggunakan skema staggered-grid. Untuk memodelkan bendungan bobol dengan data batimetri sesungguhnya akan menjadi tantangan penelitian selanjutnya, karena melibatkan geometri yang lebih kompleks.
\end{abstract}

Kata kunci: persamaan air dangkal, bendungan bobol, simulasi numerik, metode beda hingga, staggered-grid, gagal teknologi, bencana alam

\section{PENDAHULUAN}

\subsection{Latar Belakang}

Banyak fenomena alam yang dapat diselesaikan melalui pemodelan matematika. Sebagai contoh, untuk memodelkan gelombang air dapat menggunakan persamaan gelombang air dangkal. Pemodelan matematika untuk persamaan air dangkal dengan geometri yang kompleks memberikan tantangan tersendiri bagi beberapa peneliti (Gambar 1). Beberapa aplikasi untuk persamaan air dangkal antara lain untuk model bendungan bobol, aliran di saluran terbuka dan sungai, pemodelan tsunami, banjir, serta banjir bandang yang disebabkan longsor (GarcíaNavarro et al., 2019).

Selama periode 2015-2019 telah dibangun sebanyak 61 bendungan (Kementerian Pekerjaan Umum dan Perumahan Rakyat, 2020). Bendungan-bendungan tersebut diharapkan dapat berperan sebagai penyedia air baku, irigasi, dan pengendali banjir. Dalam keadaan yang tidak menguntungkan, bendungan bisa bobol karena beberapa faktor, di antaranya faktor kegagalan teknologi seperti struktur yang tidak baik, faktor bencana alam 
seperti gempa, faktor penggundulan hutan di bagian hulu maupun umur bendungan yang sudah tua. Untuk mengantisipasi dan mempelajari aliran air akibat bendungan bobol, maka sangat penting mempelajari proses aliran air akibat bendungan bobol. Sehingga dapat memberikan gambaran dan prediksi daerahdaerah terdampak akibat bendungan bobol.

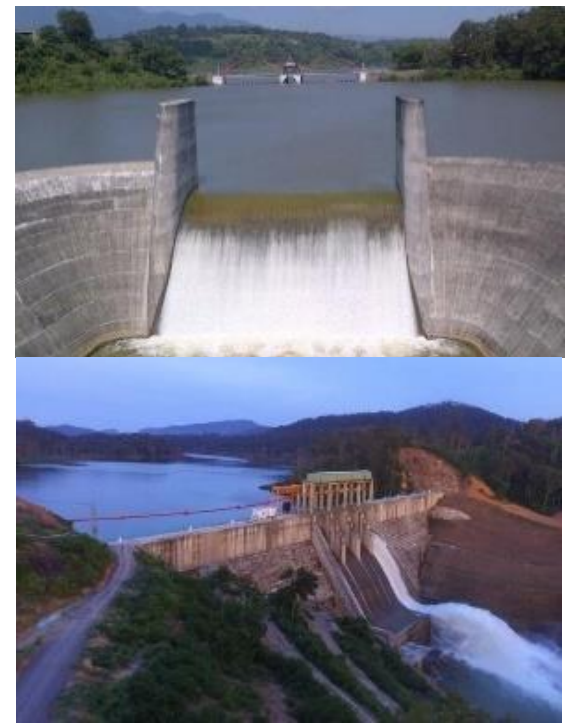

Gambar 1. Salah Satu Bentuk Geometri untuk Bendungan (Sumber: kompas.com, 2017 dan inews.id, 2018)

Fenomena bendungan bobol dapat dimodelkan dengan persamaan air dangkal, yang kemudian diselesaikan menggunakan beberapa metode numerik, seperti metode beda hingga (Saiduzzaman and Ray, 2013), metode volume hingga (Mungkasi, 2011), maupun metode element hingga. Metodemetode tersebut menggunakan grid untuk merepresentasikan sifat fisik air di titik tetap dan pada saat waktu $t$. Selain metode-metode tersebut, persamaan air dangkal juga dapat disimulasikan dengan baik menggunakan pendekatan metode Smoothed Particle Hydrodynamics (SPH) (Solenthaler et al., 2011). Dalam metode SPH air direpresentasikan dengan partikel yang memiliki sifat-sifat fisis seperti densitas, percepatan, dan energi. Dengan adanya sifatsifat fisis tersebut, interaksi antar partikel air menghasilkan gaya dan gerakan dalam domain yang ditentukan pada setiap waktu $t$.

Model bendungan bobol di kedua sisi dengan persamaan air dangkal menggunakan metode volume menghasilkan akurasi yang cukup baik (Mungkasi, 2011). Untuk menghasilkan hasil yang lebih akurat untuk pendekatan kasus realistis biasanya melibatkan jumlah sel yang banyak dan mengakibatkan biaya komputasi yang besar karena membutuhkan insfrastruktur komputer yang lebih canggih. Skema staggered-grid yang diterapkan pada metode volume hingga merupakan salah satu alternatif untuk menyelesaikan persamaan air dangkal dengan hasil yang akurat dan waktu yang dibutuhkan untuk komputasi lebih cepat (Gunawan, 2015).

Tulisan ini mensimulasikan persamaan gelombang air dangkal untuk kasus bendungan bobol menggunakan metode volume hingga dengan skema staggered-grid. Tujuannya adalah untuk melihat perubahan ketinggian permukaan air pada daerah hulu dan hilir beserta sifat perambatan gelombang air.

\subsection{Tujuan Penelitian}

Tujuan dari penelitian ini adalah untuk mengkaji dan menerapkan metode numerik yang tepat untuk masalah bendungan bobol dan memahami karakteristiknya. Untuk mencapai tujuan ini maka dalam penelitian ini dikaji beberapa metode numerik sehingga diperoleh metode yang memiliki akurasi baik serta waktu komputasi yang cepat.

\section{BAHAN DAN METODE}

\subsection{Bahan}

Bahan-bahan yang digunakan adalah buku, laporan, dan jurnal baik itu yang dipublikasikan secara internasional maupun nasional sebagai referensi untuk penelitian. Simulasi numerik dilakukan dengan menerapkan bahasa Python.

\subsection{Metode}

\subsubsection{Persamaan Air Dangkal}

Beberapa penerapan persamaan air dangkal antara lain digunakan dalam pemodelan aliran fluida baik itu di sungai, saluran, maupun di daerah pantai. Perambatan gelombang tsunami juga dapat diperoleh dengan pendekatan persamaan air dangkal, seperti yang dikembangkan dalam software TUNAMI (Imamura et al., 2006).

Aliran air dangkal dapat disketsakan dalam Gambar 2. Notasi yang digunakan antara lain $x$ mewakili jarak tempuh aliran dan $t$ mewakili variabel waktu. Persamaan air dangkal terdiri dari persamaan kontinuitas dan persamaan momentum, dengan variabel yang dicari adalah $h$ untuk ketinggian muka air dan $u$ adalah kecepatan. Syarat lain adalah panjang domain $x$ lebih dari atau sama dengan domain $h$. 


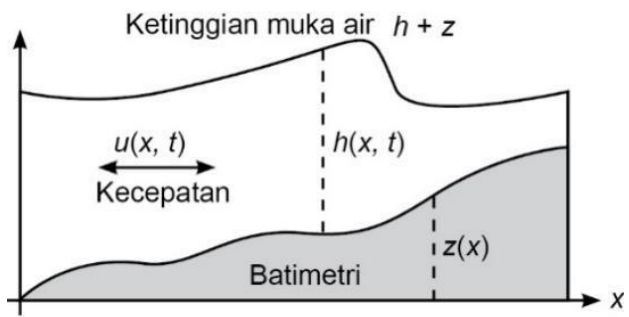

Gambar 2. Sketsa Persamaan Air Dangkal Satu Dimensi

Sistem persamaan gelombang air dangkal satu dimensi (1D) adalah sebagai berikut.

$$
\begin{aligned}
& \frac{\partial h}{\partial t}+\frac{\partial(h u)}{\partial x}=0 \\
& \frac{\partial(h u)}{\partial t}+\frac{\partial}{\partial x}\left(h u^{2}+\frac{1}{2} g h^{2}\right)+g h \frac{\partial z}{\partial x}=0
\end{aligned}
$$

dengan $t$ adalah variabel waktu, $x$ adalah koordinat, $h$ adalah ketinggian muka air, $u$ kecepatan, $g$ percepatan gravitasi dengan nilai $9,81 \mathrm{~m} / \mathrm{s}^{2}$ dan $z$ adalah batimetri dasar permukaan. Persamaan (2.1) disebut dengan persamaan kontinuitas dan persamaan (2.2) disebut dengan persamaan momentum.

Untuk sistem persamaan gelombang air dangkal dua dimensi (2D) dijabarkan dengan persamaan berikut ini.

$$
\begin{aligned}
& \frac{\partial h}{\partial t}+\frac{\partial h u}{\partial x}+\frac{\partial h v}{\partial y}=0 \\
& \frac{\partial(h u)}{\partial t}+\frac{\partial}{\partial x}\left(h u^{2}+\frac{1}{2} g h^{2}\right)+\frac{\partial(h u v)}{\partial y} g h \frac{\partial z}{\partial x}=0 \\
& \frac{\partial(h v)}{\partial t}+\frac{\partial(h u v)}{\partial x}+\frac{\partial}{\partial y}\left(h v^{2}+\frac{1}{2} g h^{2}\right)+g h \frac{\partial z}{\partial y}=0
\end{aligned}
$$

dengan $x$ dan $y$ adalah koordinat kartesius 2D $u$ kecepatan arah $x$ dan $v$ kecepatan arah $y$. Variabel lainnya sama seperti pada kasus 1D.

\subsubsection{Metode Numerik}

Pada bagaian ini menjelaskan metode numerik yang digunakan untuk menyelesaikan sistem persamaan air dangkal satu dimensi dan dua dimensi. Metode numerik yang digunakan adalah metode volume hingga dengan menggunakan skema staggered-grid (Gunawan, 2015).

\subsubsection{Skema Satu Dimensi (1D)}

Persamaan air dangkal (2.1) dan (2.2) berada dalam interval domain $\Omega=(0, L)$ dan interval waktu $(0, T)$, dengan kondisi batas periodik. Interval waktu dibagi ke dalam $N_{t}$ timesteps dengan panjang $\Delta t, n \in\left\{0,1, \ldots N_{t}\right\}$, dan $t^{n}=n \Delta t$. Interval domain dibagi ke dalam $N$ sel dengan panjang $\Delta t$. Gambar 1 menggambarkan diskritisasi untuk ketinggian muka air $h$, kecepatan air $u$, batimetri $z$ pada setiap sel. Nilai pendekatan $h$ di titik $x_{i}$ dan pada waktu $t^{n}$ dinotasikan dengan $h_{i}^{n}$. Nilai pendekatan $z$ di titik $x_{i}$ dinotasikan dengan $z_{i}$. Nilai pendekatan $u$ di titik $x_{i+\frac{1}{2}}$ pada waktu $t^{n}$ dinotasikan dengan $u_{i+\frac{1}{2}}^{n}$.

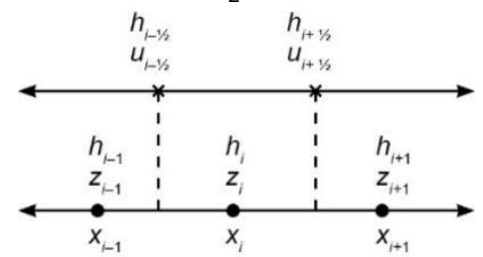

Gambar 3. Staggered-Grid untuk Model 1D

Diskritisasi dari persamaan (2.1) adalah sebagai berikut.

$$
h_{i}^{n+1}-h_{i}^{n}+\frac{\Delta t}{\Delta x}\left(q_{i+\frac{1}{2}}^{n}-q_{i-\frac{1}{2}}^{n}\right)=0
$$

dengan,

$$
\begin{gathered}
q_{i+\frac{1}{2}}^{n}=\tilde{h}_{i+\frac{1}{2}}^{n} u_{i+\frac{1}{2}}^{n} \\
\tilde{h}_{i+\frac{1}{2}}^{n}= \begin{cases}h_{i}^{n}, & \text { jika } u_{i+\frac{1}{2}}^{n} \geq 0 \\
h_{i+1}^{n}, & \text { jika } u_{i+\frac{1}{2}}^{n}<0\end{cases}
\end{gathered}
$$

Sedangkan diskritisasi dari persamaan (2.2) adalah sebagai berikut.

$$
\begin{aligned}
& h_{i+\frac{1}{2}}^{n+1} u_{i+\frac{1}{2}}^{n+1}-h_{i+\frac{1}{2}}^{n} u_{i+\frac{1}{2}}^{n}+\frac{\Delta t}{\Delta x}\left[\left(q_{i+1}^{n} \tilde{u}_{i+1}^{n}-q_{i+1}^{n} \tilde{u}_{i}^{n}\right)\right. \\
& \left.+\frac{1}{2} g\left(\left(h_{i+1}^{n+1}\right)^{2}-\left(h_{i}^{n+1}\right)^{2}\right)\right]+\frac{\Delta t}{\Delta x} g h_{i+\frac{1}{2}}^{n+1}\left(z_{i+1}-z_{i}\right)=0
\end{aligned}
$$

dengan,

$$
\begin{gathered}
h_{i+\frac{1}{2}}^{n}=\frac{1}{2}\left(h_{i}^{n}+h_{i+1}^{n}\right), \\
q_{i}^{n}=\frac{1}{2}\left(q_{i-\frac{1}{2}}^{n}+q_{i+\frac{1}{2}}^{n}\right), \\
\tilde{u}_{i}^{n}= \begin{cases}u_{i-\frac{1}{2}}^{n}, & \text { jika } q_{i}^{n} \geq 0 \\
u_{i+\frac{1}{2}}^{n}, & \text { jika } q_{i}^{n}<0\end{cases}
\end{gathered}
$$

Perhitungan error menggunakan rumus berikut ini.

$$
\operatorname{Err}=\frac{1}{N} \sum_{i=1}^{N}\left|x_{i}-\hat{x}_{i}\right|
$$

di mana $N$ adalah banyaknya sel, $x_{i}$ nilai eksak untuk sel ke- $i$, dan $\hat{x}_{i}$ adalah nilai pendekatan untuk sel ke-i.

\subsubsection{Skema Dua Dimensi (2D)}

Domain interval untuk persamaan air dangkal (2.3), (2.4), dan (2.5) adalah 
$\Omega=\left(0, L_{x}\right) \times\left(0, L_{y}\right)$, sedangkan domain waktu adalah $(0, T)$. Sama seperti pada kasus 1D, interval waktu dibagi ke dalam $N_{t}$ timesteps dengan panjang $\Delta t, \quad n \in\left\{0,1, \ldots N_{t}\right\}$, dan $t^{n}=n \Delta t$. Domain dibagi ke dalam mesh $\{1,2, \ldots$, $M\} \times\{1,2, \ldots, N\}$. Sel pada koordinat $(i, j)$, dinotasikan oleh $x_{i, j}$, dengan $i=1,2, \ldots, M$ dan $j=1,2, \ldots, N$. Nilai pendekatan $h$ di titik $x_{i, j}$ dan pada waktu $t^{n}$ dinotasikan dengan $h_{i, j}^{n}$. Nilai pendekatan $z$ di titik $x_{i, j}^{n}$ dinotasikan dengan $z_{i, j}^{n}$. Nilai pendekatan $u$ di titik $x_{i+\frac{1}{2}, j}$ pada waktu $t^{n}$ dinotasikan dengan $u_{i+\frac{1}{2}, j}^{n}$. Nilai pendekatan $v$ di titik $x_{i, j+\frac{1}{2}}$ pada waktu $t^{n}$ dinotasikan dengan $v_{i, j+\frac{1}{2}}^{n}$.

Skema 2D untuk persamaan kontinuitas (2.3) adalah sebagai berikut.

$h_{i, j}^{n+1}-h_{i, j}^{n}+\frac{\Delta t}{\Delta x}\left(p_{i+\frac{1}{2}, j}^{n}-p_{i-\frac{1}{2}, j}^{n}\right)+\frac{\Delta t}{\Delta y}\left(q_{i, j+\frac{1}{2}}^{n}-q_{i, j-\frac{1}{2}}^{n}\right)=0$ dengan,

$p_{i+\frac{1}{2}, j}^{n}=\tilde{h}_{i+\frac{1}{2}, j}^{n} u_{i+\frac{1}{2}, j}^{n}, \tilde{h}_{i+\frac{1}{2}, j}^{n}=\left\{\begin{array}{l}h_{i, j}^{n}, \quad \text { jika } u_{i+\frac{1}{2}, j}^{n} \geq 0 \\ h_{i+1, j}^{n}, \text { jika } u_{i+\frac{1}{2}, j}^{n}<0\end{array}\right.$
$q_{i, j+\frac{1}{2}}^{n}=\tilde{h}_{i, j+\frac{1}{2}}^{n} u_{i, j+\frac{1}{2}}^{n}, \tilde{h}_{i, j+\frac{1}{2}}^{n}= \begin{cases}h_{i, j}^{n}, & \text { jika } v_{i, j+\frac{1}{2}}^{n} \geq 0 \\ h_{i, j+1}^{n}, & \text { jika } v_{i, j+\frac{1}{2}}^{n}<0\end{cases}$

Pendekatan untuk persamaan momentum dengan arah- $x$ (persamaan (2.4)) adalah sebagai berikut.

$$
\begin{aligned}
& h_{i+\frac{1}{2}, j}^{n+1} u_{i+\frac{1}{2}, j}^{n+1}-h_{i+\frac{1}{2}, j}^{n} u_{i+\frac{1}{2}, j}^{n} \\
& \quad+\frac{\Delta t}{\Delta y}\left[q_{i+\frac{1}{2}, j+\frac{1}{2}}^{n} \tilde{u}_{i+\frac{1}{2}, j+\frac{1}{2}}^{n}-q_{i+\frac{1}{2}, j-\frac{1}{2}}^{n} \tilde{u}_{i+\frac{1}{2}, j-\frac{1}{2}}^{n}\right] \\
& \quad+\frac{\Delta t}{\Delta x}\left[\left(p_{i+1, j}^{n} \tilde{u}_{i+1, j}^{n}-q_{i, j}^{n} \tilde{u}_{i, j}^{n}\right)+\frac{1}{2} g\left(\left(h_{i+1, j}^{n+1}\right)^{2}-\left(h_{i, j}^{n+1}\right)^{2}\right)\right] \\
& \quad+\frac{\Delta t}{\Delta x} g h_{i+\frac{1}{2}, j}^{n+1}\left(z_{i+1, j}-z_{i, j}\right)=0
\end{aligned}
$$

dengan

$$
\begin{aligned}
& h_{i+\frac{1}{2}, j}^{n}=\frac{1}{2}\left(h_{i, j}^{n}+h_{i+1, j}^{n}\right), \\
& p_{i, j}^{n}=\frac{1}{2}\left(p_{i-\frac{1}{2}, j}^{n}+p_{i+\frac{1}{2}, j}^{n}\right), \\
& \tilde{u}_{i, j}^{n}=\left\{\begin{array}{l}
u_{i-\frac{1}{2}, j}^{n}, \text { jika } p_{i, j}^{n} \geq 0 \\
u_{i+\frac{1}{2}, j}^{n}, \text { jika } p_{i, j}^{n}<0
\end{array}\right. \\
& q_{i+\frac{1}{2}, j+\frac{1}{2}}^{n}=\frac{1}{2}\left(\begin{array}{l}
q_{i+1, j+\frac{1}{2},}^{n} \\
\text {, }
\end{array} q_{i, j+\frac{1}{2}}^{n}\right), \\
& \tilde{u}_{i+\frac{1}{2}, j+\frac{1}{2}}^{n}=\left\{\begin{array}{l}
u_{i+\frac{1}{2}, j}^{n}, \text { jika } q_{i+\frac{1}{2}, j+\frac{1}{2}}^{n} \geq 0 \\
u_{i+\frac{1}{2}, j+\frac{1}{n}}^{n}, \text { jika } q_{i+\frac{1}{2}, j+\frac{1}{2}}^{n}<0
\end{array}\right.
\end{aligned}
$$

Sedangkan pendekatan untuk persamaan momentum dengan arah-y (persamaan (2.5)) adalah sebagai berikut.

$$
\begin{aligned}
& h_{i, j+\frac{1}{2}}^{n+1} u_{i, j+\frac{1}{2}}^{n+1}-h_{i, j+\frac{1}{2}}^{n} u_{i, j+\frac{1}{2}}^{n} \\
& +\frac{\Delta t}{\Delta x}\left[p_{i+\frac{1}{2}, j+\frac{1}{2}}^{n} \tilde{v}_{i+\frac{1}{2}, j+\frac{1}{2}}^{n}-p_{i-\frac{1}{2}, j+\frac{1}{2}}^{n} \tilde{v}_{i-\frac{1}{2}, j+\frac{1}{2}}^{n}\right] \\
& +\frac{\Delta t}{\Delta y}\left[\left(p_{i, j+1}^{n} \tilde{v}_{i, j+1}^{n}-q_{i, j}^{n} \tilde{v}_{i, j}^{n}\right)+\frac{1}{2} g\left(\left(h_{i, j+1}^{n+1}\right)^{2}-\left(h_{i, j}^{n+1}\right)^{2}\right)\right] \\
& +\frac{\Delta t}{\Delta y} g h_{i, j+\frac{1}{2}}^{n+1}\left(z_{i, j+1}-z_{i, j}\right)=0
\end{aligned}
$$

\section{HASIL DAN PEMBAHASAN}

Pada bagian ini akan dibahas mengenai hasil-hasil penelitian baik dalam kasus 1D dan 2D. Untuk kasus 1D terdapat dua hasil, yaitu yang pertama adalah simulasi bendungan bobol 1D dengan batimetri datar dan yang kedua adalah tes akurasi untuk batimetri tidak datar. Sedangkan kasus 2D terdapat beberapa 
hasil simulasi, yaitu simulasi air tenang yang tiba-tiba memperoleh gangguan dan model bendungan bobol 2D. Semua simulasi menggunakan metode volume hingga dengan skema staggered-grid.

\subsection{Model Satu Dimensi}

\subsubsection{Model Bendungan Bobol 1D dengan Batimetri Datar}

Kondisi awal model bendungan bobol 1D untuk ketinggian muka air dan kecepatan air saat $t=0$ adalah sebagai berikut.

$$
h(x, 0)= \begin{cases}1, & x \leq 0,5 \\ 0,2, & x>0,5\end{cases}
$$

dan $u(x, 0)=0,0 \leq x \leq 1$. Untuk batimetri adalah datar yaitu $z(x)=0,0 \leq x \leq 1$. Keadaan awal tersebut menunjukkan bahwa bendungan bobol di titik $x=0,5$ (Gambar 3) pada saat $t=$ 0 . Pada model bendungan bobol 1D, solusi analitik yang dilakukan oleh Delestre et al. (2013), digunakan untuk menguji akurasi dari persamaan air dangkal dengan menggunakan skema staggered-grid.
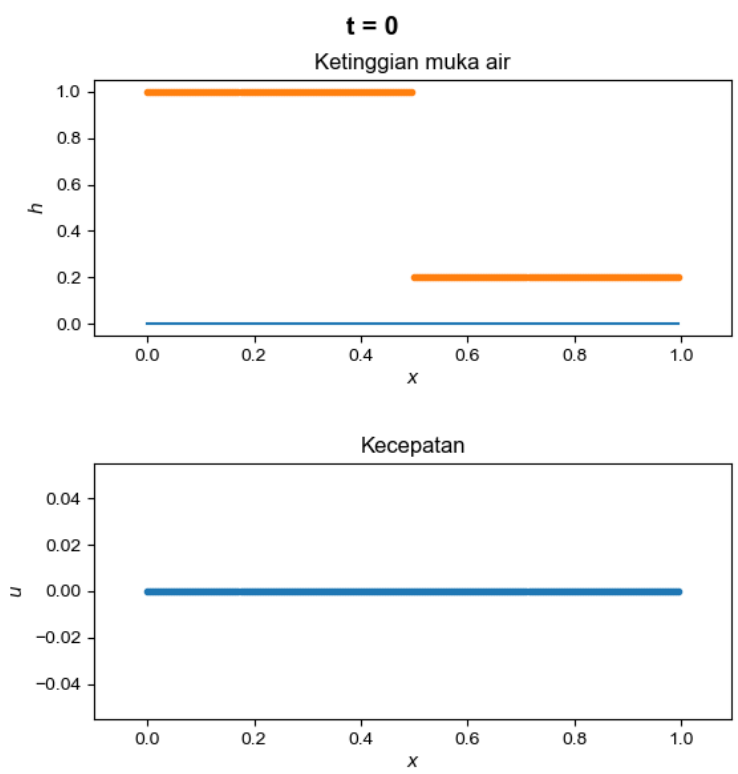

Gambar 3. Kondisi Awal untuk Ketinggian Muka Air dan Kecepatan Air Model Bendungan Bobol 1D pada $t=0$

Parameter simulasi antara lain panjang sel seragam yaitu $\Delta x=0,01$, dengan banyak sel $N$ $=200$. Gambar 4 menunjukkan perolehan hasil simulasi saat $x=0,1$. Terlihat bahwa gelombang bergerak dari kiri ke kanan ke arah permukaan air yang lebih rendah.
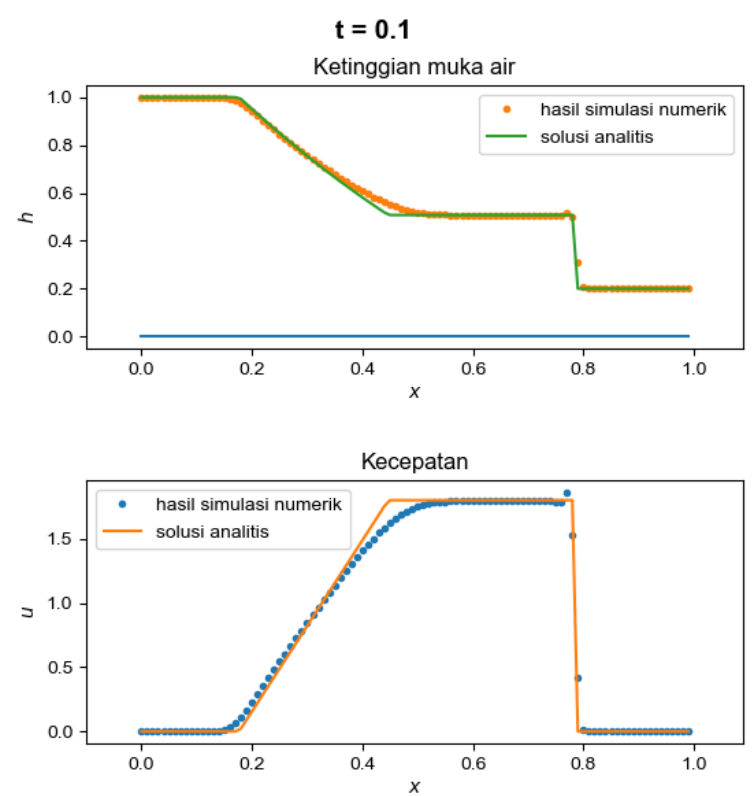

Gambar 4. Perbandingan Hasil Simulasi Numerik dan Solusi Analitis untuk Model Bendungan Bobol 1D pada $t=0,1$ (Hasil Simulasi, 2021)

Pada titik-titik sudut terdapat ketidakakuratan yang menyebabkan adanya error yang cukup jelas. Error tersebut dapat diperbaiki dengan menambah jumlah sel (Gambar 5).
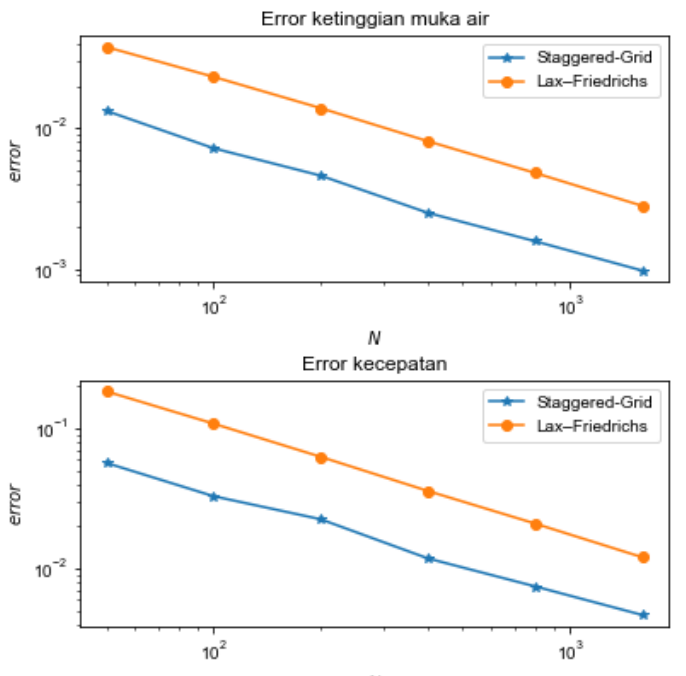

Gambar 5. Perbandingan Error antara Skema Staggered-Grid dengan Skema Lax-Friedrichs, untuk Ketinggian Muka Air $(h)$ dan Kecepatan

Air (u) pada $t=0,1$ (Hasil Simulasi, 2021)

Sebagai perbandingan, digunakan skema Lax-Friedrichs pada model bendungan bobol 1D (Setiyowati dan Sumardi, 2019). Hasilnya dapat dilihat pada Gambar 5 dan Tabel 1. Skema staggered-grid menghasilkan error 
yang lebih rendah dibandingkan dengan skema Lax-Friedrichs. Untuk kebutuhan waktu komputasi, skema staggered-grid juga memberikan hasil yang lebih cepat.

Tabel 1. Perbandingan Error antara Skema Staggered-Grid dengan Skema Lax-Friedrichs pada $t=0,1$

\begin{tabular}{|c|c|c|c|c|}
\hline \multirow{2}{*}{$\boldsymbol{N}$} & \multicolumn{2}{|c|}{$\begin{array}{c}\text { Skema Staggered- } \\
\text { Grid }\end{array}$} & \multicolumn{2}{c|}{$\begin{array}{c}\text { Skema Lax- } \\
\text { Friedrichs }\end{array}$} \\
\cline { 2 - 5 } & $\boldsymbol{h}$ & $\boldsymbol{u}$ & $\boldsymbol{H}$ & $\boldsymbol{u}$ \\
\hline 50 & $1.332 \times 10^{-2}$ & $5.649 \times 10^{-2}$ & $3.793 \times 10^{-2}$ & $1.829 \times 10^{-1}$ \\
\hline 100 & $7.217 \times 10^{-3}$ & $3.271 \times 10^{-2}$ & $2.326 \times 10^{-2}$ & $1.077 \times 10^{-1}$ \\
\hline 200 & $4.608 \times 10^{-3}$ & $2.239 \times 10^{-2}$ & $1.392 \times 10^{-2}$ & $6.240 \times 10^{-2}$ \\
\hline 400 & $2.505 \times 10^{-3}$ & $1.177 \times 10^{-2}$ & $8.099 \times 10^{-3}$ & $3.563 \times 10^{-2}$ \\
\hline 800 & $1.573 \times 10^{-3}$ & $7.433 \times 10^{-3}$ & $4.816 \times 10^{-3}$ & $2.086 \times 10^{-2}$ \\
\hline 1.600 & $9.725 \times 10^{-4}$ & $4.647 \times 10^{-3}$ & $2.809 \times 10^{-3}$ & $1.119 \times 10^{-2}$ \\
\hline
\end{tabular}

\subsubsection{Model Akurasi dengan Batimetri Tidak Datar}

Model selanjutnya adalah tes akurasi dengan menggunakan batimetri yang tidak datar (Gunawan, 2015). Domain adalah $\Omega=[0,40]$ dan fungsi batimetri adalah sebagai berikut.

$$
z(x)=\left\{\begin{array}{l}
0,48\left(1-\left(\frac{x-20}{4}\right)^{2}\right), \text { jika }|x-20| \leq 4 \\
0, \text { untuk } x \text { lainnya }
\end{array}\right.
$$

Kondisi awal untuk ketinggian muka air $h(x$, $0)=0,0 \leq x \leq 40$ dan kecepatan air $u(x, 0)=\frac{10}{4}$, $0 \leq x \leq 40$. Gambar 6 menunjukkan hasil simulasi untuk ketinggian muka air dan kecepatan air pada waktu $t=1$.
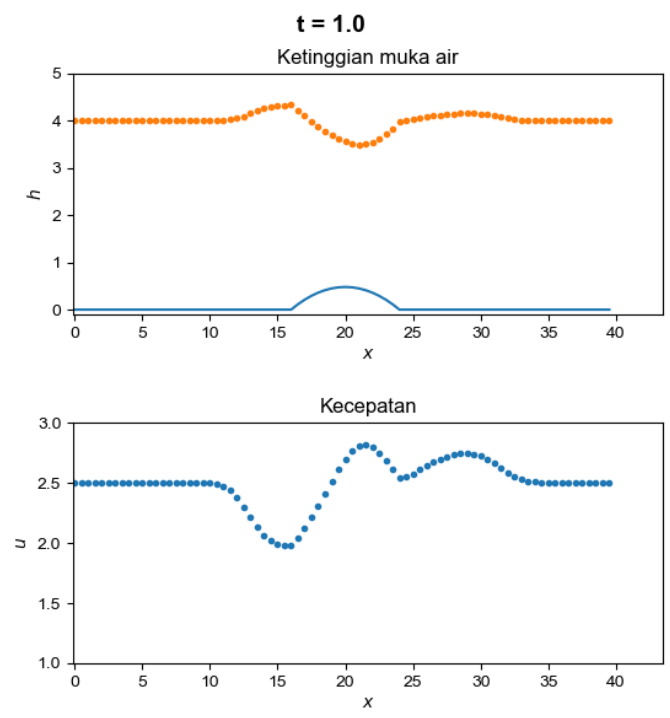

Gambar 6. Hasil Simulasi untuk Tes Akurasi dengan Batimetri yang Tidak Datar untuk Ketinggian Muka Air (Kiri) dan Kecepatan (Kanan) pada $t=0,1$ (Hasil Simulasi, 2021)

\subsection{Model Dua Dimensi}

\subsubsection{Air Tenang yang Terkena Gangguan}

Simulasi ini menggambarkan bahwa air yang tenang tiba-tiba terkena gangguan tetesan air, sehingga pada saat $t=0$, kondisi awal untuk permukaan air laut (Gambar 7) membentuk fungsi:

$$
h(x, y, 0)=0,8+0,2 e^{-\left(\frac{(x-0,25)^{2}+(y-0,25)^{2}}{0,01 \sigma^{2}}\right)}
$$

pada domain $[0,1] \times[0,1]$. Simulasi dilakukan pada saat $t=0$ sampai dengan $t=0,5$.

Pada Gambar 8a, amplitudo gelombang air pada saat $t=0,02$ mulai mengecil dan berosilasi menjauh dari sumber gangguan.

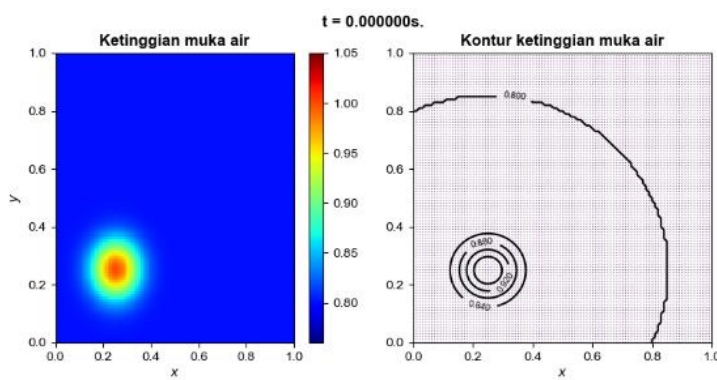

Gambar 7. Kondisi Awal untuk Simulasi Persamaan Air Dangkal 2D pada $t=0$, yaitu Tepat Saat Air Mendapatkan Gangguan (Hasil Simulasi, 2021)

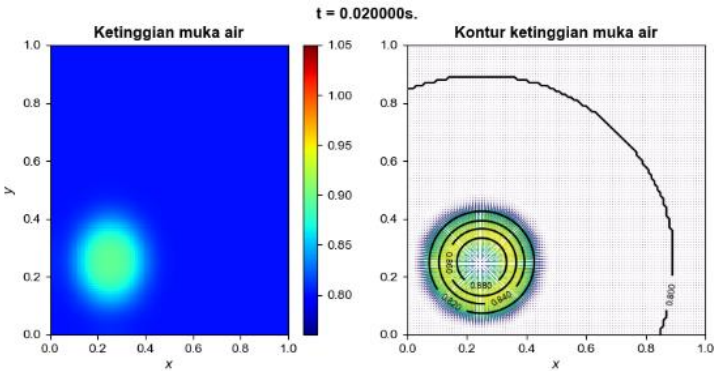

(a)

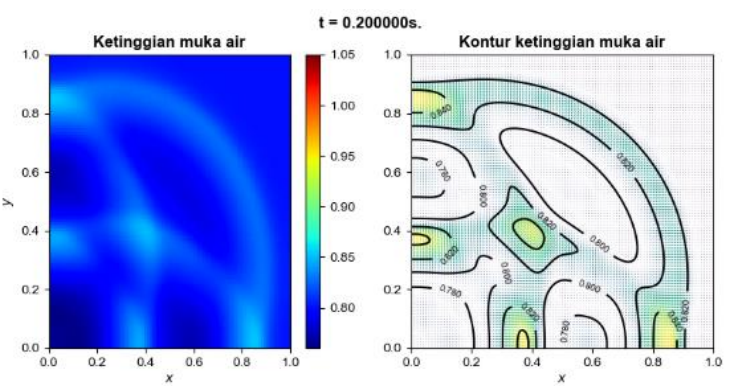

(b) 


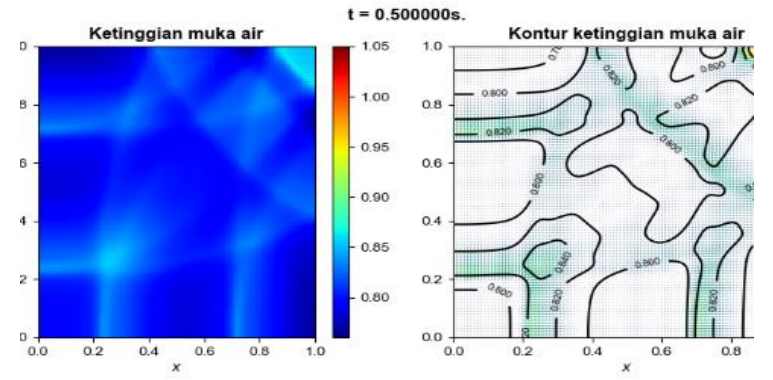

(c)

Gambar 8. Hasil Simulasi Persamaan Air Dangkal 2D untuk Ketinggian Muka Air (kiri) dan Overlay Vektor Kecepatan Air dengan Kontur Ketinggian Muka Air (Kanan) pada $t=$ 0,02 (Gambar 8a), $t=0,2$ (Gambar 8b), dan $t=$ 0,5 (Gambar 8c) (Hasil Simulasi, 2021)

\subsubsection{Model Bendungan Bobol 2D}

Permasalahan model bendungan bobol 2D terdiri dari dua skenario, antara lain dinding bendungan bobol di tengah (simetri) dan dinding bendungan bobol di samping (asimetri). Dalam model ini yang dilakukan adalah menentukan aliran yang disebabkan oleh bobolnya bendungan secara tiba-tiba, yang terjadi akibat umur bendungan yang tua, konstruksi bendungan, karena struktur pondasi yang tidak stabil, atau bahkan karena adanya bencana gempa bumi.

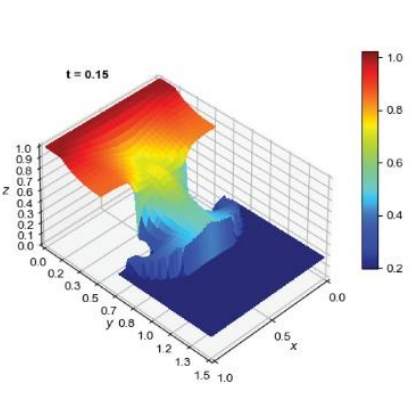

(a)

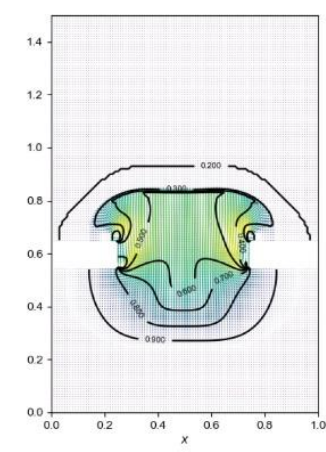

(b)
Gambar 9. Hasil Simulasi Menggunakan

Skema Staggered-Grid untuk Model Bendungan Bobol Simetri Tanpa Adanya Gesekan, untuk Ketinggian Muka Air (a) dan Overlay Vektor Kecepatan Air dengan Kontur Ketinggian Muka Air (b) pada $t=0,1$, di mana Kedalaman Air $h_{1}=1 \mathrm{~m}$ dan Ketinggian Muka Air $h_{2}=0,2 \mathrm{~m}$ (Hasil Simulasi, 2021)

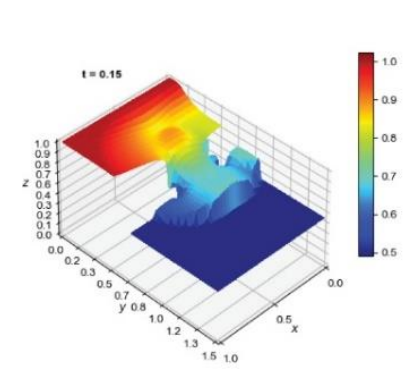

(a)

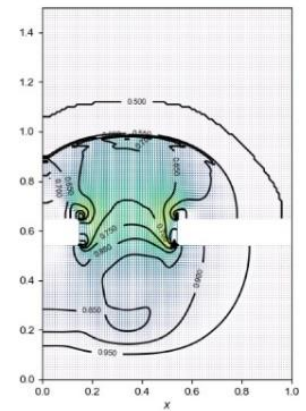

(b)
Gambar 10. Hasil Simulasi Menggunakan Skema Staggered-Grid untuk Model Bendungan Bobol Asimetri Tanpa Adanya Gesekan, untuk Ketinggian Muka Air (a) dan Overlay Vektor Kecepatan Air dengan Kontur Ketinggian Muka Air (b) pada $t=0,15$, di mana Kedalaman Air di Daerah Hulu $h_{1}=1 \mathrm{~m}$ dan Ketinggian Muka Air di Daerah Hilir $h_{2}=0,5 \mathrm{~m}$ (Hasil Simulasi, 2021)

Simulasi yang dilakukan masih dalam skala laboratorium. Domain simulasi adalah $[0,1] \times[0$, $1,5]$. Simulasi dilakukan pada saat $t=0$ sampai dengan $t=0,15$. Hasil simulasi untuk bendungan bobol dengan kerusakan bendungan tepat di tengah (Gambar 9) dan kerusakan struktur bendungan berada di tepi bendungan (Gambar 10, 11, 12) menunjukkan gelombang shock pada titik jebolnya bendungan pada waktu $t=0,15$. Kedua simulasi pada Gambar 9 dan Gambar 10 menunjukkan bahwa ketinggian air di area hulu adalah $1 \mathrm{~m}$, sedangkan ketinggian air di area hilir $0,2 \mathrm{~m}$.

Gambar 11 menunjukkan hasil simulasi kerusakan struktur bendungan berada di tepi bendungan dengan daerah hilir merupakan daerah kering. Daerah kering memiliki ketinggian muka air cukup rendah tetapi tidak nol. Terlihat jelas perbedaan vektor kecepatan air pada bagian hilir (Gambar 10b dan Gambar 11b). Vektor kecepatan pada Gambar 10b lebih halus dibandingkan vektor kecepatan pada daerah kering (Gambar 11b). 


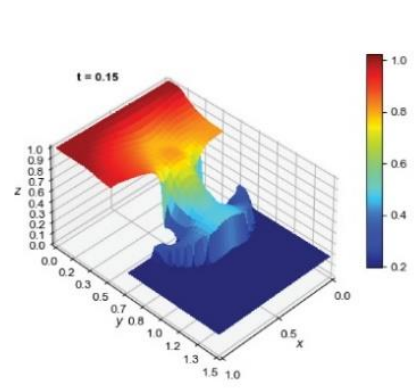

(a)

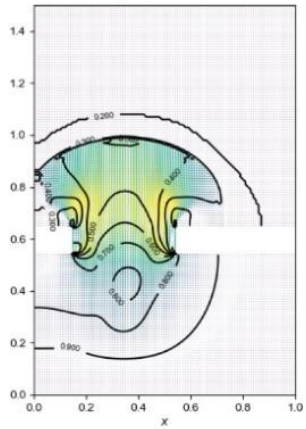

(b)
Gambar 11. Hasil Simulasi Menggunakan Skema Staggered-Grid untuk Model Bendungan Bobol Asimetri Tanpa Adanya Gesekan, untuk Ketinggian Muka Air (a) dan Overlay Vektor Kecepatan Air dengan Kontur Ketinggian Muka Air (b) pada $t=0,15$, di mana Kedalaman Air di Daerah Hulu $h_{1}=1 \mathrm{~m}$ dan Ketinggian Muka Air di Daerah Hilir $h_{2}=0,2 \mathrm{~m}$ (Hasil Simulasi, 2021)

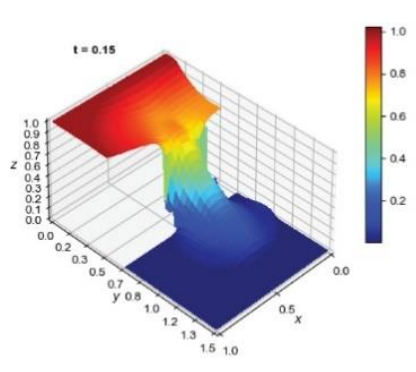

(a)

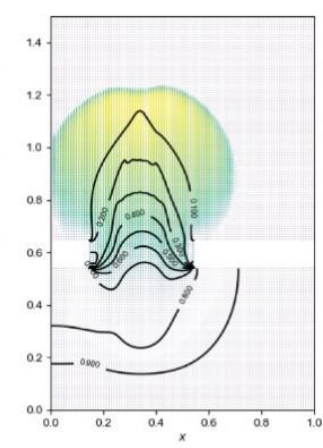

(b)
Gambar 12. Hasil Simulasi Menggunakan Skema Staggered-Grid untuk Model Bendungan Bobol Asimetri Tanpa Adanya Gesekan, untuk Ketinggian Muka Air (a) dan Overlay Vektor Kecepatan Alr dengan Kontur Ketinggian Muka Air (b) pada $t=0,15$, di mana Kedalaman Air di Daerah Hulu $h_{1}=1 \mathrm{~m}$ dan Ketinggian Muka Air di Daerah Hilir $h_{2}=0 \mathrm{~m}$ (Hasil Simulasi, 2021)

\section{KESIMPULAN}

Dalam penelitian ini telah berhasil dimodelkan bendungan bobol 2D menggunakan metode volume hingga dengan skema staggered-grid. Asumsi yang digunakan adalah tidak adanya gesekan pada permukaan batimetri dan juga pada dinding bendungan yang jebol. Untuk model asimetri, hasilnya akurat dan bisa dibandingkan dengan hasil yang juga diperoleh oleh Zoppou dan Roberts (2000). Skema staggered-grid juga menghasilkan hasil yang lebih akurat serta waktu komputasi yang lebih cepat dibandingkan dengan skema LaxFriedrichs. Selanjutnya akan dicoba skema ini untuk pemodelan menggunakan data batimetri sesungguhnya. Hal ini akan memberikan tantangan penelitian selanjutnya, karena melibatkan geometri yang lebih kompleks.

\section{DAFTAR PUSTAKA}

Zoppou, C., and S. Roberts. 2000. Numerical solution of the two-dimensional unsteady dam break. Applied Mathematical Modelling. 24 (7): 457-475.

Mungkasi, Sudi. 2011. Metode Volume Hingga untuk Menyelesaikan Masalah Bendungan Bobol. Jurnal Mat Stat. 11(1): 52-62.

Delestre, O., C. Lucas, P.A. Ksinant, F. Darboux, C. Laguerre, T.N.T. Vo, F. James, and S. Cordier. 2013. SWASHES: a Compilation of Shallow Water Analytic Solutions for Hydraulic and Environmental Studies. International Journal for Numerical Methods in Fluids. 72(3): 269-300.

Saiduzzaman, M., and S.K. Ray. 2013. Comparison of Numerical Schemes for Shallow Water Equation. Global Journal of Science Frontier Research. 13(4): 28-46.

Gunawan, H.P. 2015. Numerical simulation of shallow water equations and related models. Doctoral dissertation. Paris Est.

Setiyowati, R., and Sumardi. 2019. A Simulation of Shallow Water Wave Equation Using Finite Volume Method: Lax-Friedrichs Scheme. Journal of Physics: Conference Series. 1306(1): 012022.

Imamura, F., A.C. Yalciner, and G. Ozyurt. 2006. Tunami modelling manual. UNESCO IOC international training course on Tsunami Numerical Modelling.

Solenthaler, B., P. Bucher, N. Chentanez, M. Muller, and M. Gross. 2011. SPH-based shallow water simulation. In Virtual Reality Interactions and Physical Simulations (VRIPhys). 39-46.

García-Navarro, P. J., J. Murillo, J. FernándezPato, I. Echeverribar, and M. MoralesHernández. 2019. The shallow water equations and their application to realistic cases. Environ Fluid Mech. 19(5): 12351252.

Kementerian Pekerjaan Umum dan Perumahan Rakyat. 2020. Rencana Strategis Kementerian Pekerjaan Umum dan Perumahan Rakyat Tahun 2020-2024.

Kompas. 2017. Semua Bendungan di Indonesia Bakal Dipasangi Panel Surya. [terhubung berkala].

https://properti.kompas.com/read/2017/08/1 4/182008921/semua-bendungan-diindonesia-bakal-dipasangi-panel-surya

INews. 2018. Bendungan Jebol Sapu Permukiman di Laos, Ratusan Orang Hilang. [terhubung berkala]. 